\title{
THE COSCUEZ MINE: A MAJOR SOURCE OF COLOMBIAN EMERALDS
}

\author{
By Ron Ringsrud
}

The Muzo emerald district, in Boyach, Colombia, contains several mines. Although the Muzo mine is undoubledly the best known, the Coscuez mine is rapidly gaining significance as a major source of fine emeralds. Yet few in the trade outside of Colombia are aware of the importance of Coscuez or know about the emeralds mined there. The 'Coscuez mine is literally hundreds of years old, and its history is closely tied to that of Muzo. Located only about $10 \mathrm{~km}$ apart, the two areas also share many geologic features and both are currently exploited using open-cut mining methods. The Coscuezemeralds are similar to Muzo stones in their physical properties, but they occur in a somew hat broader range of hue and saturation. Prospects for even greater production at Coscuez in the future are good.

\section{ABOUT THE AUTHOR}

Mr. Ringsrud is a major partner in Constellation Gems, Inc., an import firm specializing in Colombian emeralds, which is headquartered in Los Angeles, California.

Acknowledgments: The author would like to thank the following people for their assistance in researching and completing this article: Samuel, Amnon, and Albert Gad; Jack and James Rotlewicz; Jorge Rozo; Eileen Weatherby; Gabriel Acuna; Dr. Alfonso Soto; Raul Escobar; Humberto Rodriguez; Guillermo Cano; Dr. Peter Keller; Dr. James Shigley; Benny Bazalel; Alberto Florez; and Cornelio Torres. Unless otherwise noted, all of the locality photos are by the author.

(C) 1986 Gemological Institute of America
$\mathrm{W}$ henever fine emeralds are discussed in the gem trade, the term Muzo is invariably used to describe the best. Yet Colombia's Muzo district actually encompasses several mines, of which two are currently major producers: Muzo and Coscuez. Many stones properly referred to as "Muzo emeralds" actually come from Coscuez (figure 1), which lies only $10 \mathrm{~km}$ from the Muzo mine (figure 2). Although smaller than Muzo, the Coscuez mine has for more than 300 years produced some of the best emeralds from the Muzo region, at times in quantities that have even surpassed the Muzo mine.

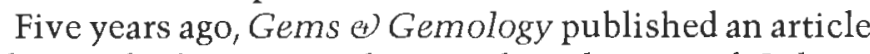
outlining the history, geology, and production of Colombia's two major emerald-mining regions: Muzo and Chivor (Keller, 1981). Soon after that article appeared, however, production from the Chivor region began to fall, while that from the Coscuez mine accelerated rapidly. During this same period, the Muzo mine continued to supply good quantities of emeralds. Today, most of the emeralds mined in Colombia come from the Muzo district, and the Coscuez mine has grown to become the second largest producer of emeralds in Colombia.

Yet in spite of its prominence, little has been written specifically on Coscuez or the Coscuez emeralds in the jewelry and gemology literature, and few in the trade outside of Colombia are aware of its importance as a major source of fine emeralds. In March 1984, the author traveled to Coscuez in the company of local dealers; two years later, in May 1986, he revisited the mine as a guest of Colombian Mines Co., a major stockholder of ESMERACOL, the present leaseholder of the Coscuez mine. Based on information gathered during these visits as well as from other sources, this article reviews the fascinating history of mining at Coscuez, describes the geology of the area and the nature of mining operations, and examines the gemology of the Coscuez emeralds. 


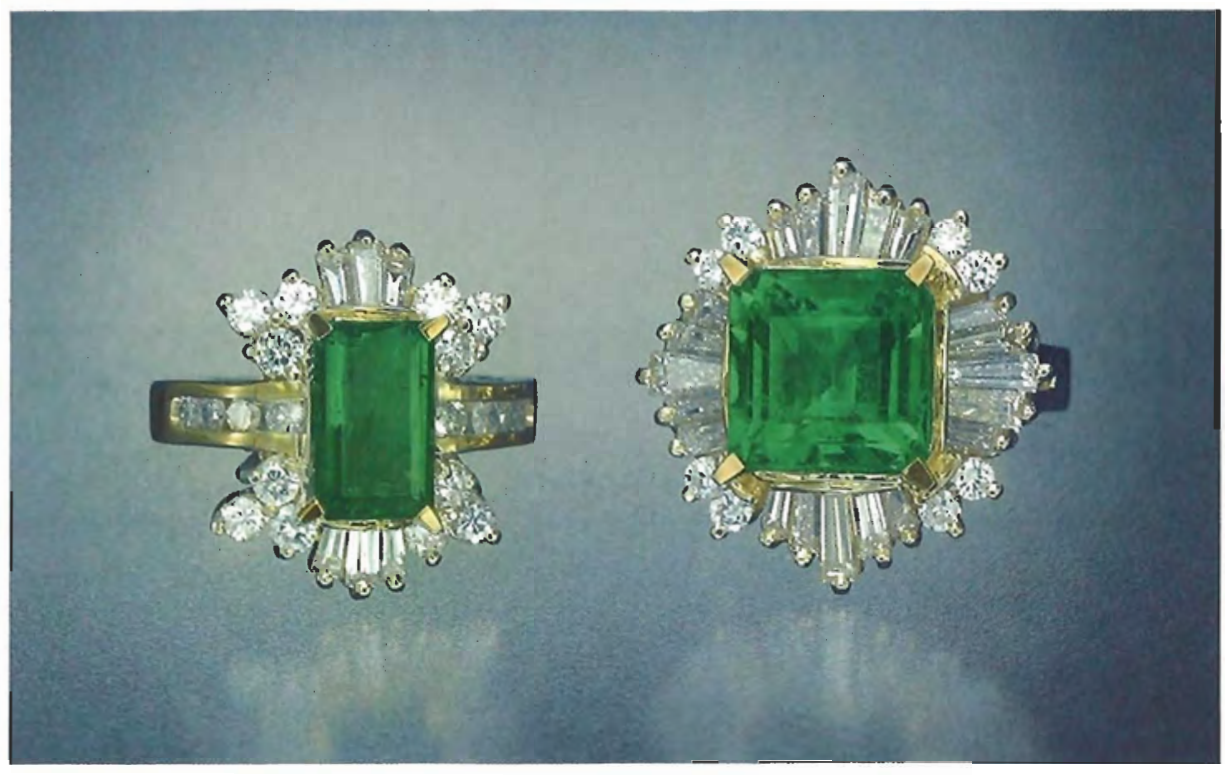

Figure 1. The emeralds (weighing 1.76 and $5.19 \mathrm{ct}$, respectively) in these two rings represent some of the brighter, cleaner material found at the Coscuez mine, a major source of emeralds in the Muzo district of Boyaca, Colombia. Jewelry courtesy of Constellation Gems, Inc.; photo (c) Harold ed Erica Van Pelt.

\section{HISTORY}

Much interesting history about the Spanish discovery and conquest of the emerald regions of Colombia was published in 1948 by the Bank of the Republic after it took over the administration of emerald mining from the government. The author was G. Otero Muñoz, head of the Colombian Institute of History. Unlike many other publications, Esmeraldas de Colombia provided considerable information specifically on Coscuez. Much of what follows is from this source.

In their conquest of South America, beginning in the 16th century, the Spaniards encountered Colombian emeralds among the local Indians as far north as Mexico and as far south as Peru and northern Chile (Sinkankas, 1981). Judging from the emeralds found in these ancient Indian sites, archaeologists believe that pre-Colombian tribes began to systematically mine and trade emeralds as early as 1000 A.D. (Sinkankas, 1981). In the region near present-day Bogotá, Spaniards led by Gonzalo Jimenez de Quesada easily conquered the Chibcha and Fusagasugae Indians. From the Chibchas, the Spaniards learned of an emerald mine at a place called Somondonco, which they located in 1537 and later renamed Chivor (Wokittel, 1960). The Chibchas also told them of another rich emerald area to the northwest. But to penetrate this region, the Spaniards would first have to subdue a far more formidable tribe: the Muzos. The Muzos were known as the most warlike, ferocious, and valiant Indians in the region, and further were reported to be cannibals. They were famous not only for their poison arrows, but also for their hidden jungle traps, camouflaged pits, and numerous fortifications.

The Muzos inherited from their ancestors the ancient legends surrounding the Fura-Tena, a colossal pair of granite peaks (the tallest is $625 \mathrm{~m}$ above the Minero River), approximately $40 \mathrm{~km}$ from the Coscuez mine. As one approaches from the east, the Fura-Tena looms up majestically as a sentinel to all who enter the emerald region. One Muzo legend states that Fura is the prince and Tena is the princess, both born to the god of the mountains. The god gave them wealth in the form of rich veins of emeralds, one of which was sacred and not to be touched. A devil named Zarv convinced the princess to take the forbidden stones. As she and the prince attempted to remove the cursed emeralds, the god turned them into the two granite peaks, and their tears of remorse became the Minero River.

In 1538, Spanish Captain Luis Lanchero launched the first campaign against the Muzo Indians (Piedrahita, 1881). Although Lanchero was forced to retreat after much fighting, accounts of the campaign show that while butchering local wild turkeys for food, he and his soldiers found small emerald crystals in the craws. This was more than enough incentive to convince the colonial governors to continue attempts to conquer that region. More campaigns were launched against the Muzos in 1545, 1550, and 1551, but these too were ultimately unsuccessful.

In 1558, however, Lanchero reentered Muzo territory with a force consisting of Spanish soldiers and members of local tribes that were also at war 

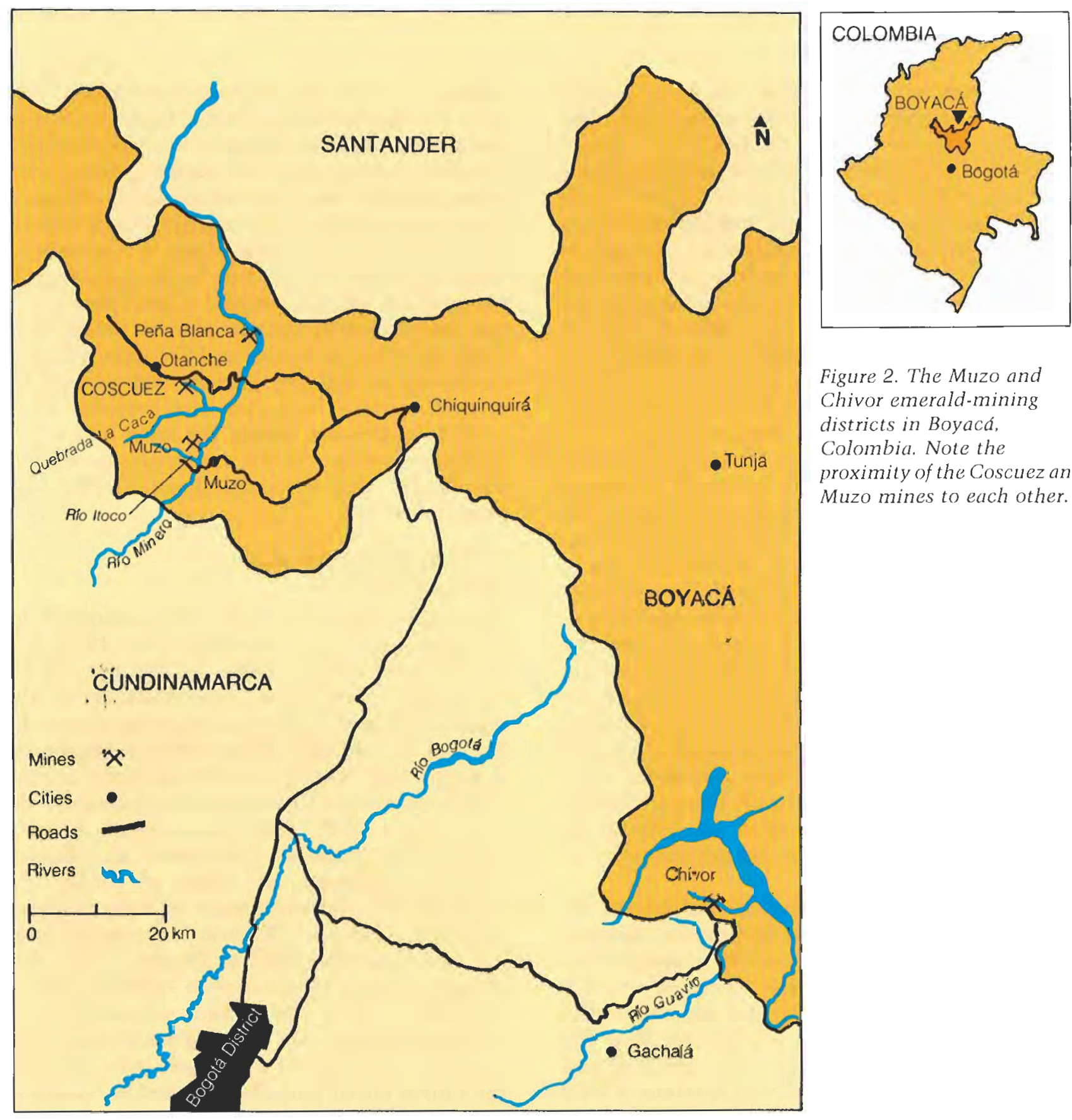

Figure 2. The Muzo and Chivor emerald-mining districts in Boyacá, Colombia. Note the proximity of the Coscuez and Muzo mines to each other.

with the Muzos. Up until this confrontation, the steel swords, armor, and firearms that had been adequate to conquer local Indian tribes throughout much of the continent had not been enough to subdue the Muzos. Their defeat was ultimately brought about by Lanchero's timely use of a new weapon: ferocious European hunting dogs. When the dogs were turned loose in mid-battle, they created havoc and confusion in the ranks of the Indians (figure 3). In two costly and decisive battles, Lanchero and his forces finally succeeded in bringing the land of the Muzos under Spanish control.

Following their success, in 1559 Lanchero's men created a settlement close to where the Indians' emerald mines were supposed to be and called it Santísima Trinidad de los Muzos. Captain Lanchero and his men soon located the mines and began to work them in the name of the Spanish Crown. Coscuez, named after an Indian princess, had been worked by the Indians for centuries prior to the conquest and was undoubtedly one of the 
first located by the Spaniards. Ironically, a chest wound that Lanchero had received more than two decades earlier in his first battle with the Muzos had never healed, and in 1562 it turned gangrenous and killed him. Yet the value of the legacy he left was evident in the eventual establishment of a royal counting house, a royal treasury, and numerous cathedrals in the town of Muzo. The cost to the Muzo Indians, however, was dear: Enslavement to work the mines and exposure to new diseases introduced by the Spaniards killed thousands. Eventually the loss of slave labor led to a steady decline in emerald production, and the seat of local government was moved from Muzo to Tunja.

Spanish records indicate that in July of 1646 there appeared in the city of Muzo a Captain Francisco de Ovalle, carrying a royal seal that named him Lord of Mines and overseer of all that he discovered in the Coscuez heights "as long as the rocks there show the green of the emerald." This situation caused some official confusion at first, because the mine was already known and being worked by others. In those days, however, the governorship changed hands frequently, and in 1647 the new governor accepted the captain's claim. This is one of the first instances on record where the Coscuez mine was considered separately. Up until this time, in the history recorded by the Spaniards as well as in the government concessions and leases, the Coscuez mine was included with Muzo.

During the colonial period, the miners extracted the emeralds simply by following the good veins with tunnels. At Coscuez, a magnificent 18-oz. (550-ct) crystal was extracted by this method, and was reportedly sent to a museum in Madrid. In the mid-1600s, a large cave-in at the Coscuez mine buried almost 300 Spaniards and Indians. Work in the area was abandoned soon after. Two centuries later, in 1850, mining operations uncovered the same tunnel complete with the bones of the victims and their bamboo and metal tools (C. Torres, pers. comm., 1986). The vein became known to the miners as the Dead Man's Underpass, and today goes by the name El Español (The Spaniard).

In 1824 , the newly independent government of Colombia leased the mining area around Muzo to Colombian mineralogist José Ignacio Paris, who controlled the mining operations for the next 22 years. During this period, acting on the advice of English mining engineer George Cheyne, Paris changed the operation at Muzo from tunneling to open-cut mining, using a form of benching, that is, cutting the slopes horizontally in a step-like fashion and washing away the resulting debris with water. Because water was not as readily available, Coscuez was worked less extensively at this time, and mainly by tunneling. Paris is remembered today primarily for his part in the discovery at Muzo of the mineral parisite, a rare fluorocarbonate of cerium that was named in his honor. After Paris, a number of foreign and Colombian lessees continued to work the deposits with varying degrees of success. Little has been recorded about activity at Coscuez during the latter half of the 19 th century except that it was repeatedly worked, abandoned, and reopened (Pogue, 1916; Oppenheim, 1948).

\section{RECENT HISTORY AND PRODUCTION}

The Muzo mine was responsible for most of the emeralds produced in the district from 1925 until it was closed again in 1938. In 1946, the Colombian government turned responsibility for the mining and marketing of all emeralds over to the Bank of the Republic. The bank was unable to maintain tight control, however, so illegal mining and black marketing of emeralds flourished. Finally, in 1969, the government formed ECOMINAS (Empresa Colombiana de MinasColombian Ministry of Mines) to control the mines. In 1977, private companies were sought to work the mines on a five-year lease arrangement ["Coscuez, an Emerald Mine Reborn," 1979). The Coscuez lease was awarded to ESMERACOL, a company whose present major stockholders are Colombian Mínes Co. (a Bogotá-based cutter, broker, and exporter), Victor Quintero (who also runs the Chivor mine), Jaime Murcia, and the family of the late Juan Francisco (Pacho) Vargas.

Through ECOMINAS, the Colombian government records the number of carats of emeralds legally exported each year. Until 1968, totals for many of the individual mines were reported; since then, inexplicably, records show only totals exported from all mines. In addition, illegal mining and unreported exporting diminish greatly the reliability of the official statistics. It is not surprising, then, that the author was unable to obtain any accurate, detailed production figures, either from the government offices or from the mine officials. However, trends can be seen in the ECOMINAS 


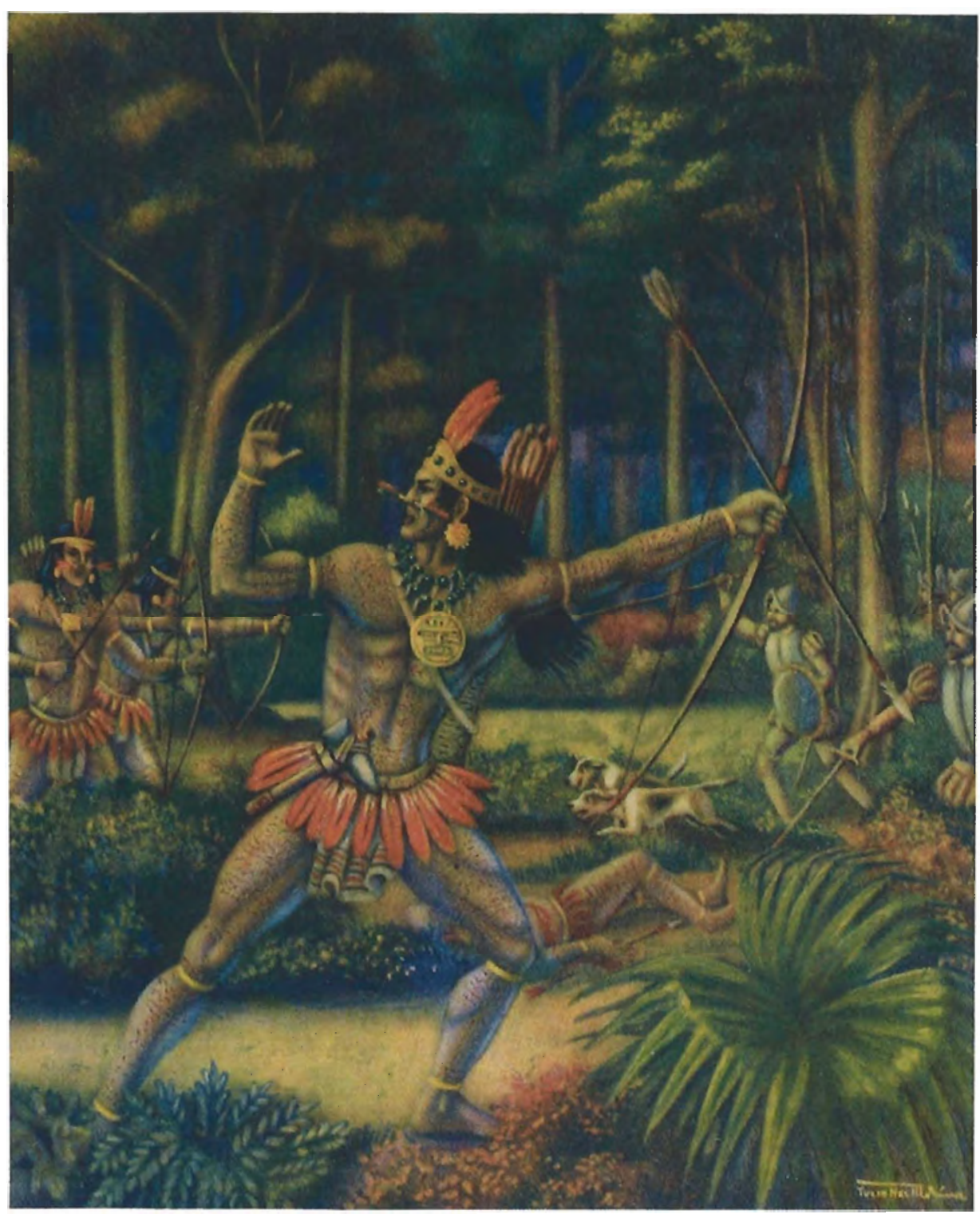

Figure 3. Adorned with emeralds, the Muzo Indians fought the Spanish invaders fiercely. Ultimately, European hunting dogs were a deciding factor in Captain Luis Lanchero's defeat of the Muzos in 1558. From Otero Muñoz (1948). Reproduced by permission of the Colombian Institute of History.

records that substantiate the recent decline in production from the Chivor mine, continued strong production from the Muzo mine, and significantly greater production from the Coscuez mine. For example, totals in the ECOMINAS production registry show that the Chivor mine averaged 10,000$40,000 \mathrm{ct}$ of gem-quality emeralds per year during the 1920s and 1930s, and 10,000-20,000 ct annually until 1963, when production dropped and stayed low. Dealers in Bogotá who are familiar with the market reported to this author that in the 1960s and 1970s Chivor production was erraticwith some good and some bad years - but that it has stayed low since 1980 .

ECOMINAS records show that Muzo also averaged 10,000-40,000 ct of gem-quality emeralds per year during the 1930s and 1950s, but that production increased after 1963. Dealers in Bogotá estimate that Muzo is currently producing several hundred thousand carats of emeralds annually. Production at the Coscuez mine, unreported until 1960 , exceeded 25,000 ct in 1963, even surpassing Muzo for that year. Mr. Samuel Gad, a major partner in Colombian Mines Co., estimates that more than $150,000 \mathrm{ct}$ of emeralds per year are now being mined at Coscuez (pers. comm., 1986).

\section{LOCATION AND ACCESS}

The Andes Mountains begin in southern Chile and define the entire western edge of South America until they reach Colombia in the north, where the chain divides into three prongs covering the west- 
ern portion of the country. The world's richest emerald-bearing region straddles the easternmost prong, known as the Cordillera Oriental. The Muzo district lies due north of Bogotá, the capital of Colombia, in the northern part of this emeraldbearing zone. The Muzo and Coscuez mines lie within $10 \mathrm{~km}$ of each other in the state of Boyacá lat $5^{\circ} 33^{\prime} \mathrm{N}, 74^{\circ} 11^{\prime} \mathrm{W}$ and $5^{\circ} 39^{\prime} \mathrm{N}, 74^{\circ} 11^{\prime} \mathrm{W}$, respectively). Access to the mining region from Bogotá is accomplished by helicopter, traveling approximately $105 \mathrm{~km}$ (70 mi.) due north, or by field vehicle, traveling $260 \mathrm{~km}$ over what are primarily winding paved and unpaved roads that descend from the high flat plain on which the capital city is situated to the mountainous subtropical terrain of the lower altitudes.

The Muzo mine is about $800 \mathrm{~m}(2,625 \mathrm{ft}$. $)$ above sea level and the Coscuez mine, $1120 \mathrm{~m}$. In both places, the land is fertile and the vegetation thick. The weather at both mines is warm, although the heat at Muzo-which lies in a natural valley, sheltered from the wind-can be oppressive.

In spite of their close proximity, Muzo and Coscuez are not connected by any road. To get to Coscuez from Muzo by automobile, one has to go $90 \mathrm{~km}$ east and then, just before Chiquinquirá, take a second road northwest for approximately 90 $\mathrm{km}$. A narrow footpath between the mines can be traversed in less than five hours. This path, as well as the roads that lead to the mining areas, is used only by the locals in that specific region. Territoriality is strong and has resulted in many local rivalries and skirmishes. Until conditions change, these areas should be visited only with extreme caution and in the company of local residents.

\section{GEOLOGY}

The Coscuez mine (figure 4) is one of several mines in the Muzo district, which also includes the Peña Blanca as well as the famous Muzo mine. The mines in the district are located within roughly 30 $\mathrm{km}$ of one another. Despite this close proximity, there is no evidence that the mines are linked in any way or that they are part of one continuous deposit. However, an understanding of the local geology has been hampered by the dense vegetation, rough topography, and limited detailed scientific study of the entire area. Further investigations under way may reveal a more direct relationship between the separate emerald deposits.

The geology of the Muzo district has been de- scribed by several authors, including Pogue (1916), Schiebe (1933), Clements (1941), and Oppenheim (1948). This work is summarized in Sinkankas (1981) and Keller (1981). In general, the district is underlain by a great thickness of shales of early Cretaceous age. These shales are intensely folded. In addition, the area is transected by a number of northeast-trending faults that are accompanicd by zones of brecciation.

Historical observations along with recent studies of these faults have shown that they are frequently concentrated at locations either of existing emerald mines or areas of emerald mineralization. Thus, plans are under way to use fault patterns as promising exploration targets in future prospecting for emeralds in the Muzo district and in surrounding areas in this part of Colombia. On a more local scale, experience has shown that areas of emerald mineralization are indicated by certain changes in the color or texture of the host rock or by areas of water seepage from the rocks which may indicate the presence of a fault.

In the Muzo district, the geologic formation in which the emeralds are found is known as the Villeta formation of Lower Cretaceous age (120-130 million years old). This formation and other sedimentary rocks in the area are rich in fossils, thus allowing for their age dating. The Villeta formation consists of a great thickness of black, carbonaceous shales and minor amounts of limestone. As with the other rocks in the district, the rocks of the Villeta formation have been intensely folded, faulted, and fractured. The Villeta formation was divided into two members by Lleras (1929). The underlying member consists of black carbonaceous shales and thinly bedded limestones. The overlying member is composed of black to yellowish gray shales. Locally, these two members are separated by two thin layers, which consist of calcite and minor quartz in a matrix of fine limestone cement; the difference between the two layers is principally textural.

As at Muzo, the rocks of the Villeta formation at Coscuez are cut by numerous calcite veins that partly or completely fill fractures in the sediments. The veins vary up to $35 \mathrm{~cm}$ in thickness and up to several meters or more in length. Having formed along fractures in the host rock, the veins are oriented in various directions within the rock but often cut across the original bedding plane of the sediments. The orientation of the veins can, however, often be directly correlated with the local 


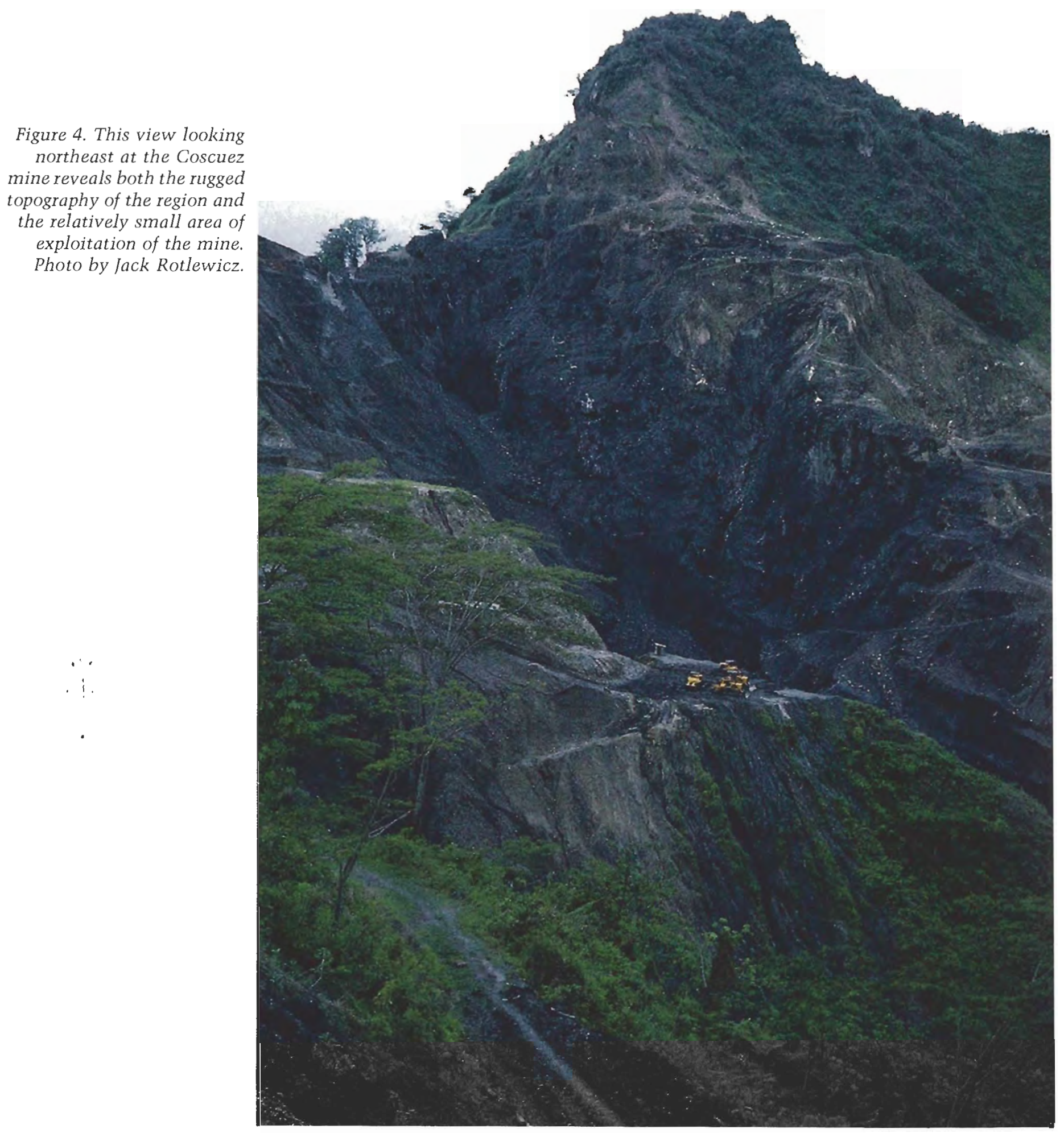

pattern of fracturing in the rock. In some instances the veins intersect. The fractures are generally filled by the calcite vein material, but occasionally there are open cavities within the calcite which may contain free-standing crystals.

For the most part, the emerald crystals are found with the calcite along these fractures in the shale and limestone. The shale and limestone are often discolored, with a yellowish gray appearance, in the area of the mineralized calcite veins. The emerald crystals usually occur attached to the wall of the fracture and are surrounded by calcite, or they may be embedded within the calcite itself. Field observations indicate that the best-quality emeralds seem to be found in the narrower veins $(5-10 \mathrm{~cm}$ thick). Barriga Villalba (1948) hypothe- 


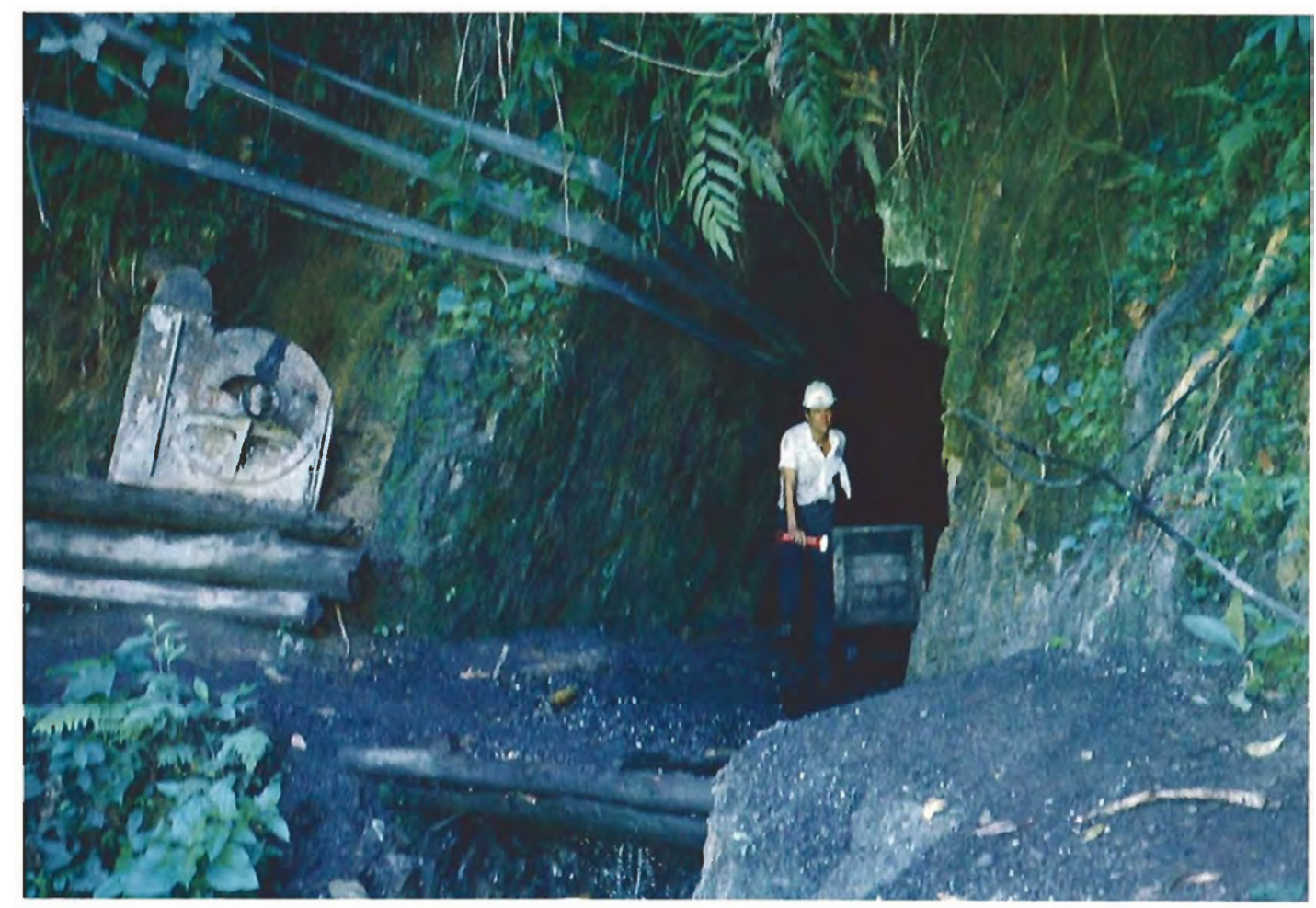

Figure 5. Below Coscuez, the Túnel la Tabla penetrates $600 \mathrm{~m}$ into the mountain as the miners follow the emerald-bearing calcite veins. Note the plastic tubes used to deliver air into the tunnel. Until recently, tunneling was the principal method of mining at Coscuez. sized that this might be due to the mineralizing solutions and gasses entering the narrow fissures with higher pressure, providing for better crystallization, but this has not been further evaluated. The crystals are randomly distributed, but locally concentrated, within the calcite veins and can occur either singly or in groups. Associated with the emerald in the calcite veins are minerals such as pyrite, quartz, dolomite, parisite, and (rarely) fluorite, apatite, albite, and barite. "Trapiche" emeralds, as well as both dolomite and pyrite, are more common at Muzo than they are at Coscuez. Although the surface area of the Muzo mine is 10 to 15 times larger than Coscuez, the latter has a greater concentration of emerald-bearing veins.

The origin of the Coscuez, Muzo, and other emerald deposits in this region has long been the subject of geologic study but as yet has not been satisfactorily explained. Following their deposition, the sedimentary rocks of the Muzo district were subjected to a period of folding, faulting, and metamorphism. During these events, hydrothermal solutions appear to have been derived from within the sediments or from unidentified igneous sources. These solutions leached beryllium and other elements from the rocks occurring over a large area. Moving along zones of weakness in the rocks, such as fault zones, the solutions deposited emerald and other minerals along fractures in the metamorphosed sediments. Although there is general agreement as to the basic features of this model of emerald formation, many questions await answers from further geologic study.

\section{MINING}

Historically, the rugged topography and steepness of the mountain on which the Coscuez mine is located have made access to Coscuez more difficult than Muzo (figure 4). In addition, the emerald-bearing sedimentary rock at Coscuez is somewhat harder than that found at Muzo. The harder host rock, along with the fact that Coscuez does not have abundant water available, has made open-cut mining difficult until relatively recently. Tunneling has been the chosen mining method throughout the history of Coscuez. One tunnel, begun privately over 19 years ago, penetrates 600 $m$ upward and into a mountain close to the main mine area (figure 5). The tunnel follows emeraldbearing calcite veins and has produced enough in the past to keep a small group of locals occupied working it today. As heavy machinery became available in recent years, the more efficient opencut mining became possible. Now the mine is worked with five bulldozers and some limited use of dynamite (figure 6). As the potentially emerald-bearing calcite veins are uncovered, they are checked by the miners with picks and then worked by hand if emeralds are found (figures 6 and 7). 
tailings from the mine are washed by the river and yield enough emeralds to support up to 10,000 people. The mine owners stay within the mine and the guaqueros generally stay at the river. In Coscuez, however, there is no river, only La Culebrera. Although local miners report that the stream can support more than 2,000 people, the author has seen only 50 or so (figure 8). It is more common in this area that the guaqueros enter the mine property at night and dig numerous tunnels in search of emeralds (figure 9). Territorial disputes among the guaqueros make security and control a problem in both Muzo and Coscuez, but with a stream that supports only a small number of people and a smaller surface area to exploit, the job of securing Coscuez is more difficult. It is interesting to note that the guaqueros of this region consist mainly of descendants of the Muzo and Colima Indians. The reputations that the guaqueros at the different mines have of aggressiveness and hostility tend to correlate directly with how deeply into the territory of the Muzo Indians the mine is found. Chivor and Gachalá, which are outside of what was once the territory of the Muzos, are relatively safe mines and can even be visited by tourists. The Muzo mine, to the north, in Muzo territory, is considered dangerous for visitors, and Coscuez slightly more so. North of Coscuez, the Peña Blanca mine is deepest in the heart of the Muzo Indians' old territory and correspondingly has by far the worst reputation of all the mines for danger and hostility among the locals.

\section{GEMOLOGY}

Crystallization. Observations by local miners have suggested that the Coscuez emerald can occur in more complex crystal forms than the Muzo emerald. While both mines produce many simple prismatic crystal forms, at Coscuez are found a large number of emeralds that are aggregates of three to six or more crystals all with individual terminations (figure 10). The faces tend to be brilliant with little or no etching. The crystals found at Muzo are generally shorter and less likely to have terminations and aggregates than at Coscuez. This phenomenon may have been caused by a lack of open space in the vein during crystallization, which could have inhibited crystal growth. Oppenheim (1948) speaks of the Coscuez emeralds as being "famous for their exceptional green color and elongated crystals."

Color. In Colombia, the different mines are known to produce emeralds that differ slightly in color, tone, and clarity. Muzo emeralds tend to be a well-saturated slightly yellowish green, while Chivor emeralds are generally less saturated and more bluish green. Dealers in Bogotá maintain that the best crystals (in terms of clarity and "life") come from Gachalá. About Coscuez, though, these same dealers have a saying: "From Coscuez comes a little of every (Colombian) mine." There is no one specific hue or degree of clarity associated with Coscuez emeralds; rather, a variety of hues occur, some of which are illustrated in figure 11 . Sometimes Coscuez crystals are lively, clean, and lightly saturated in color like those from Gachalá, sometimes the material is very bluish like Chivor, and sometimes there is absolutely no difference from Muzo color and quality. However, one type of emerald commonly seen is typical only of Coscuez (but by no means the only materiall. Using the terminology of the GIA Colored Stone Grading System, this type of Coscuez emerald can be described as a strongly saturated, slightly bluish

Figure 9. The face of this hill at Coscuez is literally covered with tunnels that the local guaqueros have dug in the dark of night searching for emeralds. Photo by lack Rotlewicz.

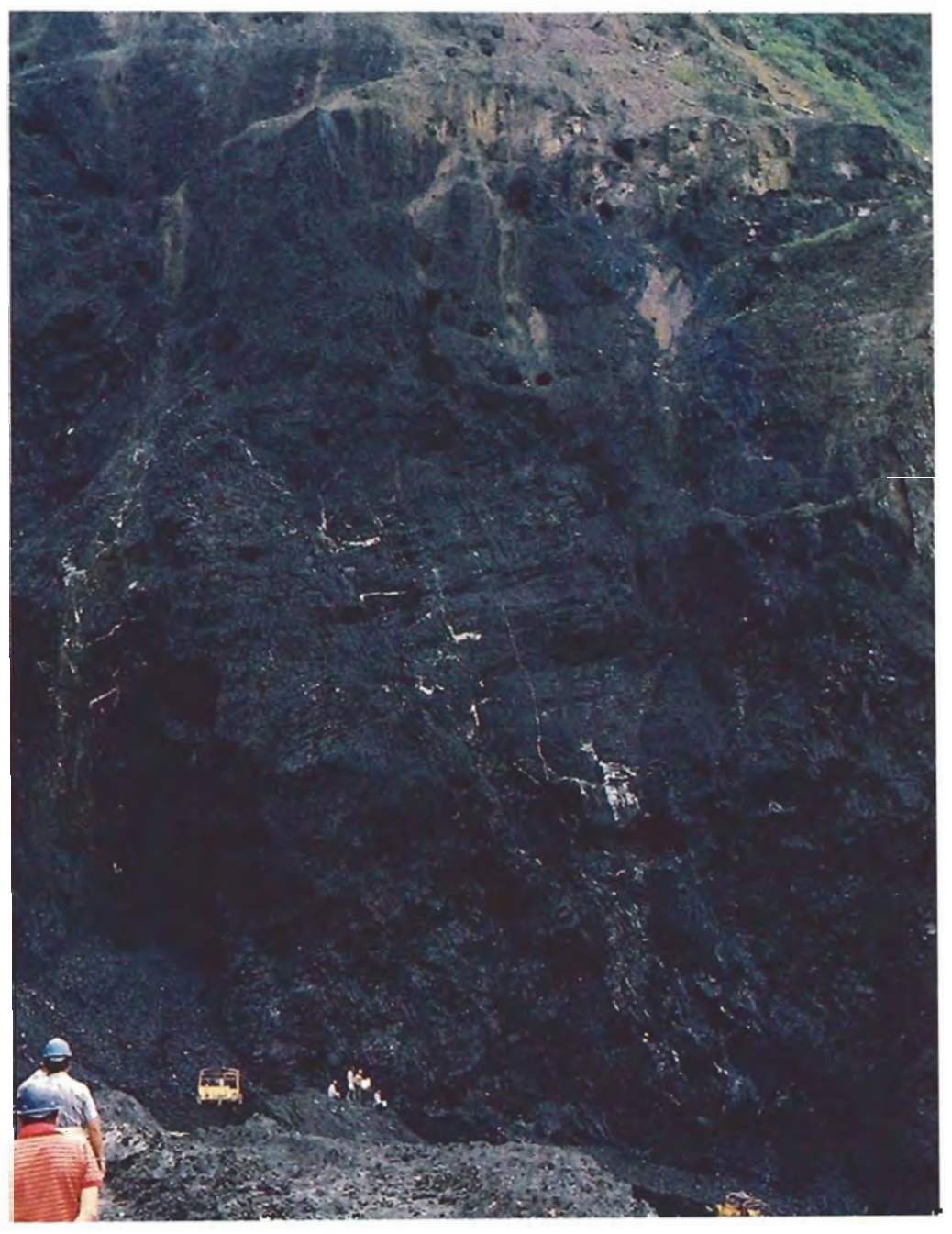




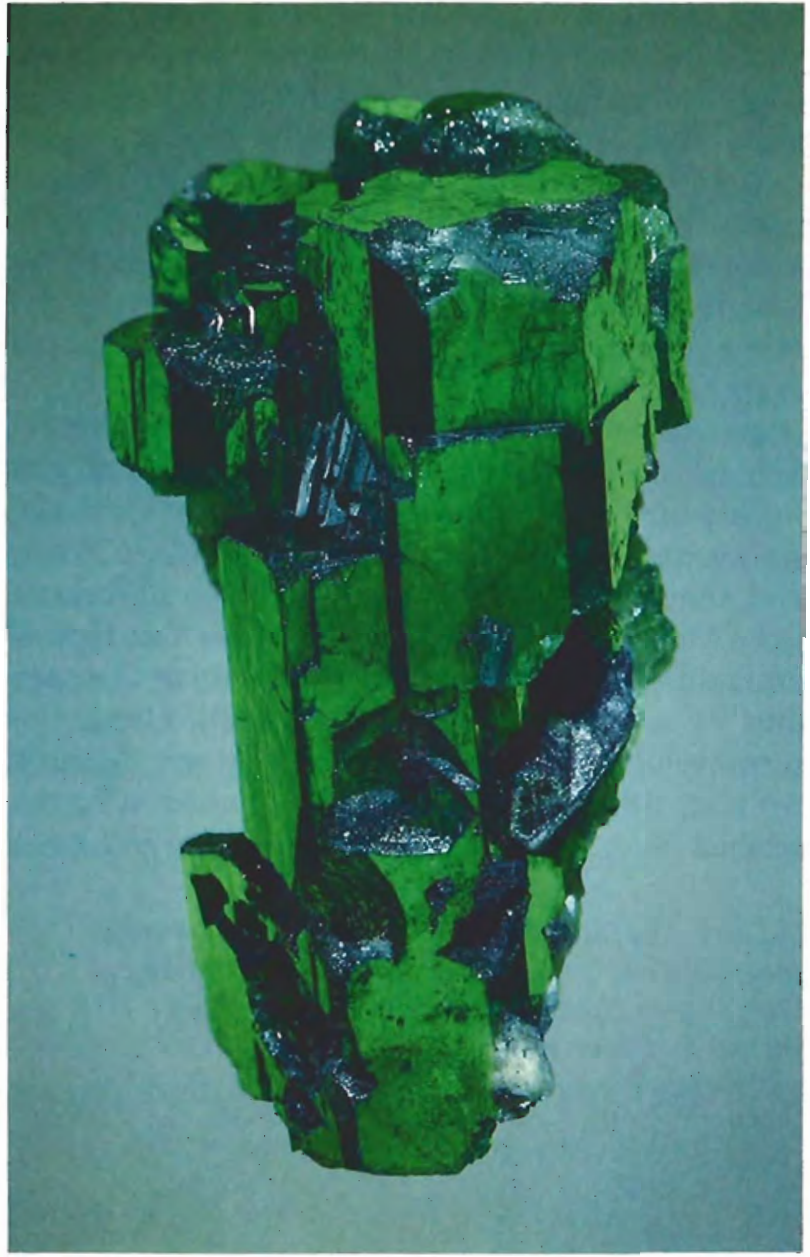

Figure 10. Note the multiple terminations on this $100+-c t$ emerald crystal from Coscuez. The highly saturated color evident here is also commonly seen in Coscuez emeralds. Specimen courtesy of AMGAD, Inc., New York; photo (C) Harold (4) Erica Van Pelt.

green stone with a medium dark to very dark tone. Often the tone is so dark that transparency and "Iife" are diminished. These stones are still very attractive, especially to those who appreciate strongly saturated color over brilliancy and transparency. Although the best color from Muzo is better than the best from Coscuez, many Coscuez emeralds are among the finest that Colombia has to offer. A top stone from Coscuez recently sold in New York for over US $\$ 25,000$ per carat.

It should also be noted that Muzo-mine rough is sometimes extremely color zoned, with a pale central core and darker, more saturated color on the crystal's outer edges or "rind." Coscuez rough, however, is generally uniform in color throughout the crystal.
Physical Properties. The properties of Coscuez emeralds do not vary significantly from those of Colombian emeralds in general: refractive index, 1.574-1.580; birefringence, $0.006-0.007$; specific gravity, $2.68-2.71$; inert or slightly pink, orange, or red when exposed to long-wave ultraviolet radiation, and inert to short wave; pink to red when viewed with the emerald filter.

Inclusions. A preliminary examination with the microscope of approximately 50 faceted and rough emeralds from Muzo and Coscuez revealed no significant differences in the number or type of inclusions. Emeralds from both sources have two- and three-phase inclusions and the typical in ternal features associated with Muzo-district material: "coaly" inclusions of carbonaceous matter, as well as calcite, albite, pyrite, quartz, and (rarely) barite, fluorite, and apatite. However, the main "jardin" feature of Coscuez and other Colombian emeralds is simply partially healed fractures. A seemingly endless variety of shapes and sizes of partially healed fractures and voids are found, which suggests interrupted and/or incomplete healing of fractures in the material. However, Muzo stones do seem to have more three-phase inclusions that are visible at lower magnifications $(10 \times$ to $20 x)$ than other emeralds from Colombia, while the partially healed fractures in Coscuez emeralds seem to be slightly more unidirectional than Muzo stones.

\section{FUTURE POTENTIAL}

Because of the difficult terrain and the dense overgrowth, systematic exploration of the Muzo and Chivor emerald districts has never taken place. In 1984, however, ECOMINAS geologists were able to define the boundaries of the potential emeraldbearing region in to a polygon that reached from the Chivor-Guavio region to the Muzo-Coscuez region (again, see figure 2). Within those boundaries, analyses of the fault patterns mentioned earlier in this article have revealed several high-probability areas for emerald exploration; some are very close to Muzo and Coscuez, and others are in areas that have never before been explored (A. Florez, pers. comm., 1986).

A cooperative technical survey and study (1984-85) performed by United Nations scientists and Colombian geologists also showed promising results as well as some new geochemical guides for emerald exploration. For regional prospecting, the sodium content of stream sediments was recom- 


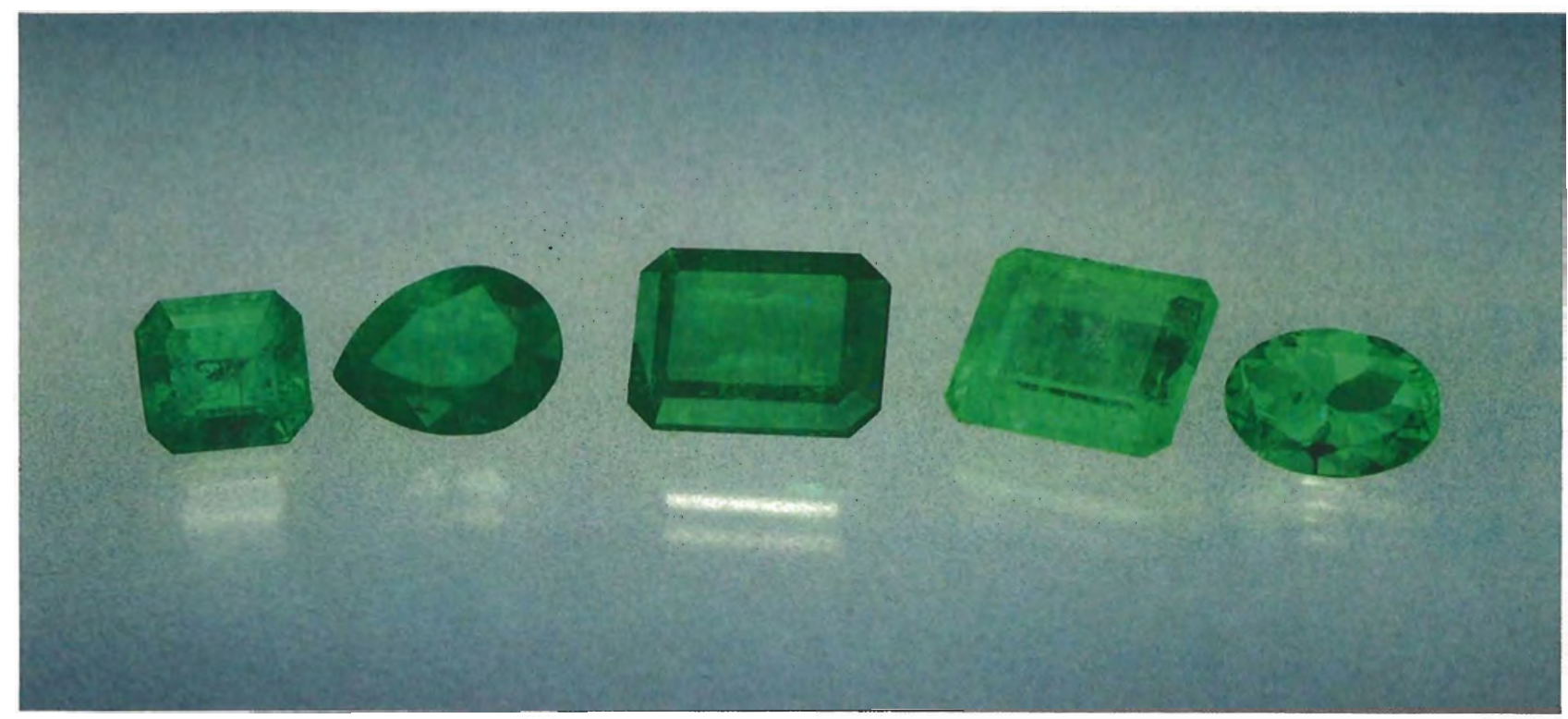

Figure 11. These faceted emeralds illustrate the range of hues, saturation, and "life" seen in Coscuez stones. The 1.69-ct oval stone is reminiscent of Gachala material, while the 1.89-ct emerald cut at the opposite end and the 4.34-ct emerald cut next to the oval could easily have come from Muzo. The 2.51-ct pear shape and accompanying 4.51-ct emerald cut in the center are of a tone and saturation that comes only from Coscuez. Stones courtesy of Constellation Gems, Inc.; photo (C) Harold e) Erica Van Pelt.

mended as a strong probable indicator of emeraldbearing deposits in nearby rock formations. Guided by the technical report, ECOMINAS geologists will begin prospecting in fall 1986 using the amount of sodium, lithium, and lead found in the soils of various areas as a guide.

Locally at Coscuez, the emerald-bearing sediments are in many places $50 \mathrm{~m}$ thick and thus far exploitation has depleted very little of the immediately workable deposits. Promising reserves are abundant, as is the optimism of ESMERACOL officials (J. Rotlewicz, pers. comm., 1986). By contrast, mining at Peña Blanca ceased recently because the emerald beds had been depleted in the main area and solid black shale bedrock encountered (A. Florez, pers. comm., 1986).

\section{CONCLUSION}

Because Coscuez lies in the Muzo district, the term Muzo emerald can apply to a Coscuez-mine stone. However, the Coscuez mine should be recognized for what it is: one of the world's most important emerald mines and worthy of consideration on its own.

Although there are many similarities in the historical development of the Muzo and Coscuez mines and in the emeralds found there, there are also differences in the geology of the two areas, the crystals produced, and the predominant color and clarity of the stones mined. Studies are currently being conducted by the Colombian government to better understand the geology of this region and identify new deposits. All current indicators are, however, that the potential for continued strong production of emeralds at Coscuez is good.

\section{REFERENCES}

Barriga Villalba A.M. (1948) Estudio científico. In Esmeraldas de Colombia, Banco de la República, Bogotá, Colombia.

Beus A.A. (1970) Algunos rasgos geológicos de la región de esmeralda Muzo-Coscuez. ECOMINAS, Bogotá, Colombia.

Clements T. (1941) The emerald mines of Muzo, Colombia Gems \&) Gemology, Vol. 3, No. 9, pp. 130-133.

Coscuez, an emerald mine reborn (1979). ColombianAmerican Business, Vol. 16, p. 6.

Keller P. (1981) Emeralds of Colombia. Gems e) Gemology, Vol. 17, No. 2, pp. $80-92$.

Lleras C.R. (I929) Minas de esmeraldas. Boletín de Minas y Petroleos, Vol. 1, No. 1.

Oppenheim V. (1948) The Muzo emerald zone, Colombia, South America. Economic Geology, Vol. 43, pp. 31-38.

Otero Muñoz G. (1948) Leyenda e historia. In Esmeraldas de Colombia, Banco de la Republica, Bogotá, Colombia.

Piedrahita L.F. de (1881) Historia General de las Conquistas del Nuevo Reino de Granada. Bogotá, Colombia.

Pogue J. (1916) The emerald deposits of Muzo, Colombia. Transactions of the American Institute of Mining and Metallurgical Engineers, Vol. 55, pp. 810-834.

Schiebe R. (1933) Informe geologico sobre la mina de esmeraldas de Muzo. Compilación de los Estudios Geológicos Oficiales en Colombia, Vol. 1, pp. 169-198.

Sinkankas J. (1981) Emerald and Other Beryls. Chilton Book Co., Radnor, PA.

Technical Report \#1683 on Emerald Project (1984-5). United Nations, Washington, D.C., in cooperation with the Colombian government.

Wokittel R. (1960) Recursos minerales de Colombia. Compilación de los Estudios Geológicos Oficiales de Colombia, Vol. 10 , pp. $341-352$. 